\title{
The Social Impact of the Gulf Oil Disaster Diverging Views From Communities in Florida and Louisiana
}

$\mathrm{R}$ esidents along the Gulf of Mexico coast experienced a wide range of impacts from the record-breaking oil spill that followed the explosion, in April 2010, of a British Petroleum (BP) oil rig. Louisiana and Florida residents received the largest share of BP-related claims, reflecting the substantial economic burden these states faced in connection to this disaster. ${ }^{1}$ It will be years before the area can accurately assess the amount of damage to the region's coastal environment, marine ecosystems, and its economically and culturally important fishing, oil, and tourism industries.

\section{CERA Survey in the Gulf Coast}

Since 2007, the Carsey Institute's Community and the Environment in Rural America (CERA) initiative has surveyed almost 19,000 rural Americans about the socioeconomic and environmental changes in their lives and communities. As part of the CERA initiative, Carsey researchers surveyed 2,023 residents of the Gulf Coast following the BP Deepwater Horizon oil rig explosion in 2010 (see Figure 1). During the late summer, while oil was still gushing into the Gulf of Mexico, telephone interviews were conducted with 1,017 residents of Louisiana's Plaquemines and Terrebonne parishes and 1,006 residents of Florida's Bay, ${ }^{2}$ Gulf, and Franklin counties. ${ }^{3}$ Respondents were asked how they perceived the oil spill to be affecting their families, communities, and the environment, their levels of trust in sources of information about the spill, and whether they perceived institutional responses to the spill as effective. Data was also gathered about respondents' general demographic characteristics. ${ }^{4}$

This brief uses data from the CERA survey ${ }^{5}$ to analyze residents' perceptions of the spill shortly after the incident. This research provides important insights that can inform disaster relief efforts in the future to better meet the needs of those affected.

\section{Key Findings}

- $\quad$ Nearly one-half of all Gulf Coast residents (48 percent $^{6}$ ) perceived damage to the environment and wildlife as the most serious result of the oil spill.

- Perceptions regarding the impact of the spill reflect the economic differences in the two states-Floridians are most concerned about effects on tourism and Louisianans on the fishing and oil industries.

- The majority of Gulf Coast residents thought that the economy, fishing industry, beaches, and wildlife would recover within a few years after the spill.

- Gulf Coast residents had little faith in BP to rectify the situation after the oil spill. Fifty-nine percent did not trust the information BP provided about the spill, and 69 percent thought BP was doing a poor or fair job responding effectively to the spill.

- Although more than one-half of the respondents from both states experienced either major or minor economic effects from the Gulf oil spill, only 16 percent of Floridians and 18 percent of Louisianans have been compensated or expect that BP will compensate them for the losses.

- Louisianans were more than twice as likely as Floridians to think that their state and local governments were doing an excellent job responding to the spill. Approximately threefourths ( 77 percent) of Gulf Coast residents thought that the federal government was doing a poor or fair job responding.

- Nine out of ten Gulf Coast residents plan to remain in the region despite the economic and environmental impacts of the spill. Those planning to move because of the spill are more likely to be Louisianans than Floridians. 
Louisiana and Florida have received similar economic compensation from BP (amounting to \$698 million and $\$ 682$ million, respectively ${ }^{7}$ ). Although it is still uncertain what the long-term damage will be to either state's economy, communities, or natural environment and wildlife, the perceptions that residents have regarding the spill are important to consider. Despite the roughly equivalent economic compensation, Louisiana and Florida residents differ in perceptions about the current and long-term effects of the largest marine oil spill in U.S. history. ${ }^{8}$ Residents of Louisiana were more likely than Floridians to say their family suffered major economic setbacks because of the spill, to expect compensation by BP, and plan to leave the region as a result of the spill. Louisianans were also more likely to think their state and local governments were doing an excellent job responding to the spill and to trust newspapers as a source of information regarding the spill.

\section{Perceived Effects of the Spill on Families, the Environment, and Gulf Economies}

Louisianans more often reported that the spill had affected their family's well-being, as may be expected because of Louisiana's closer proximity to the spill site (see Figure 1). Forty-four percent of Louisianans perceived major effects, compared with 26 percent of Floridians (see Figure 2).

Although more than one-half of the respondents from both states experienced either major or minor economic effects from the spill, only 16 percent of Floridians and 18 percent of Louisianans were compensated or expect to be compensated by BP for the losses. BP has already compensated many Gulf Coast residents, but others have been turned down, are still awaiting compensation, or continue to struggle as a result of the spill. In addition, some effects of the spill may take years, even decades, to surface and may be difficult to link directly to the BP spill. ${ }^{9}$

\section{Figure 1. Cera Gulf Coast Survey Counties and Parishes in Relation to Deepwater Horizon} and to Shoreline Oiled by the Spill

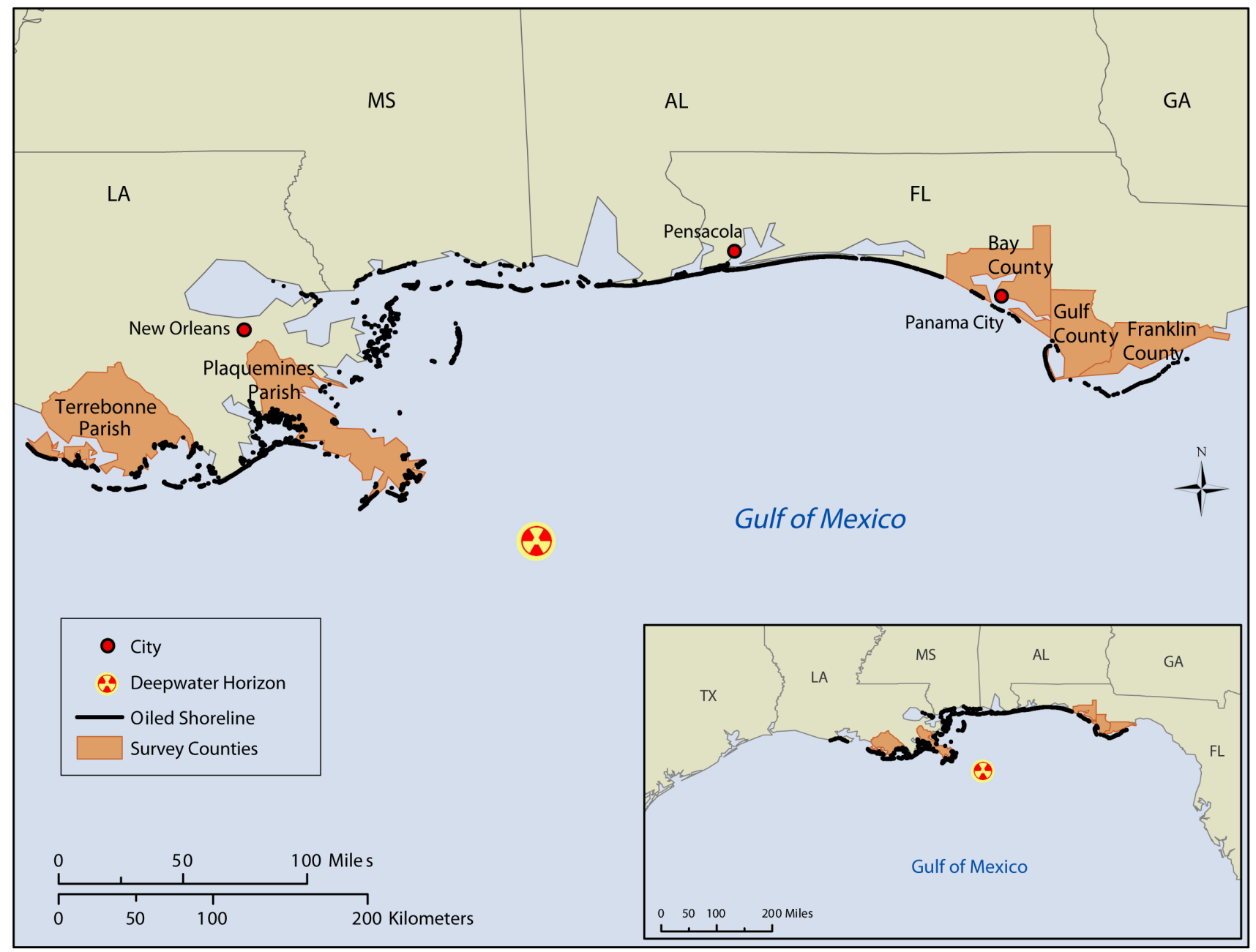

Map created by Barbara Cook 
Figure 2. "WOULD YOU SAY THAT THE BP DEEPWATER HORIZON OIL SPILL HAS HAD MAJOR EFFECTS, HAD MINOR EFFECTS, OR HAS HAD NO EFFECTS ON YOU AND YOUR FAMILY'S ECONOMIC WELLBEING?"

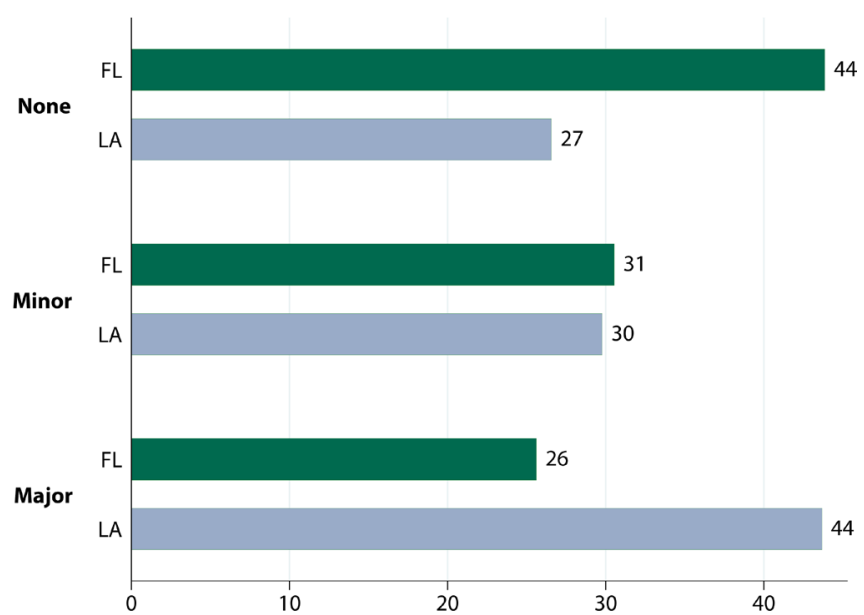

Gulf Coast residents were also asked in which of the four areas effects of the spill were most widely felt: environment/ wildlife, fishing industry, tourism industry, or the oil industry (see Figure 3). The majority (48 percent) of Gulf Coast residents perceived the most serious result of the spill to be damage to the natural environment and wildlife. Floridians, however, were significantly more concerned than Louisianans about the effects on the environment and wildlife. Over one-half (54 percent) of Floridians considered environment and wildlife impacts as the most serious result of the spill. Although many (39 percent) Louisiana respondents also saw environmental impacts as most serious, they were significantly more likely than Floridians to see the economic impacts on the fishery or oil industries as most serious. Eighteen percent of Florida respondents, but only 4 percent from Louisiana, saw tourism impacts as the most serious. (Although tourism is important to New Orleans, it matters

FIGURE 3. "IN YOUR OPINION, WHAT IS THE MOST SERIOUS RESULT FROM THIS OIL SPILL?”

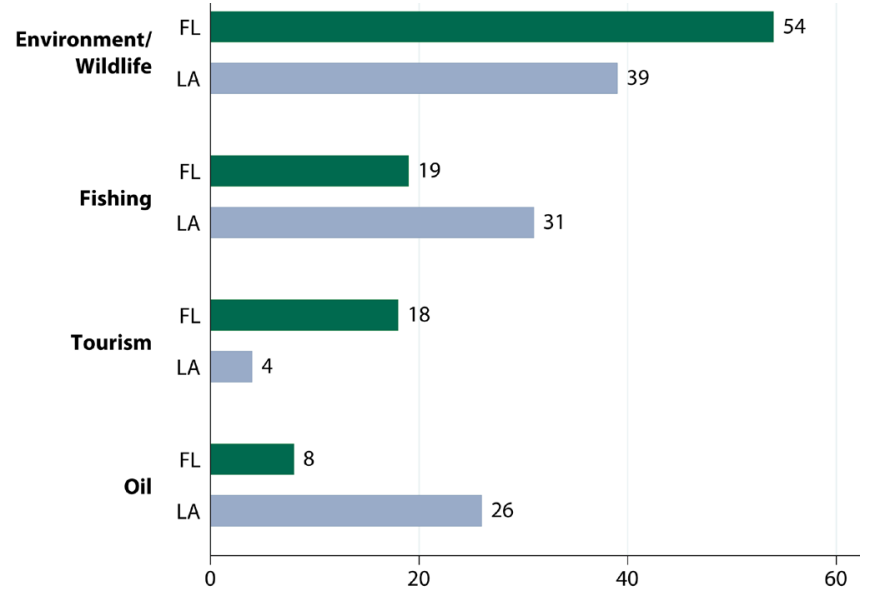

much less than fishing or oil-related work in the coastal Louisiana parishes CERA surveyed.) The higher priority of environment, beaches, and tourism in coastal Florida matches that region's economic foundation, as does the higher salience of oil and fisheries in coastal Louisiana.

Three questions asked how long respondents thought it would take for the economy (see figure 4a), fishing industry (see Figure 4b), or beaches and wildlife (see Figure 4c) to recover from the spill. Possible answers ranged from "may never" to "within a year, once the oil spill is stopped." For all three questions, more Florida respondents took either the most pessimistic or the most optimistic views of recovery times, while Louisiana residents inclined toward the middle ground. The majority (about 40 percent) of all residents thought that the economy, fishing industry, and beaches and wildlife would recover within a few years, while the fewest number of respondents (about 9 percent) thought that the economy, fishing industry, and the region's environmental assets would never recover.

Figure 4A. Perceptions of Damage from the BP Oil SPILL: ECONOMIC RECOVERY

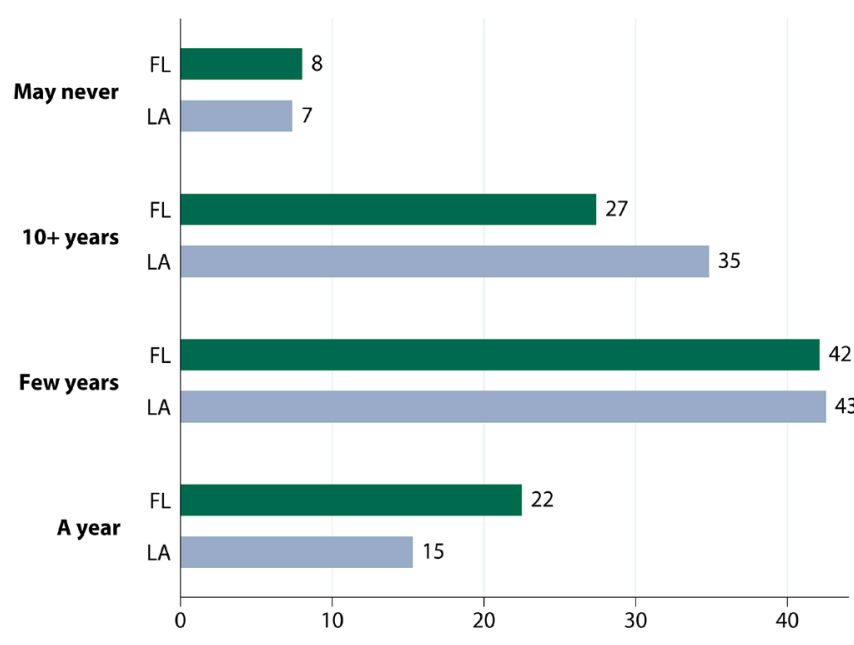

Figure 4B. Gulf Fishing Industry Recovery

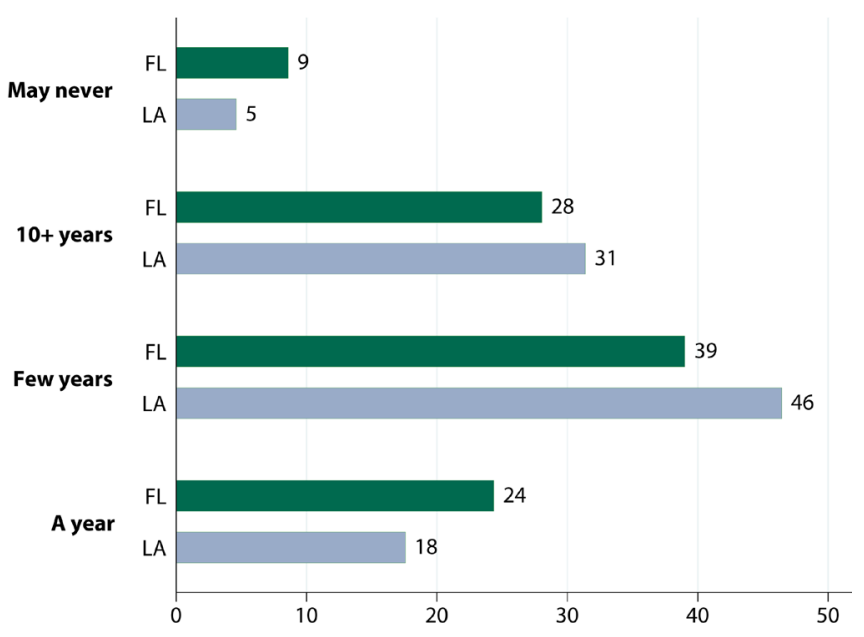




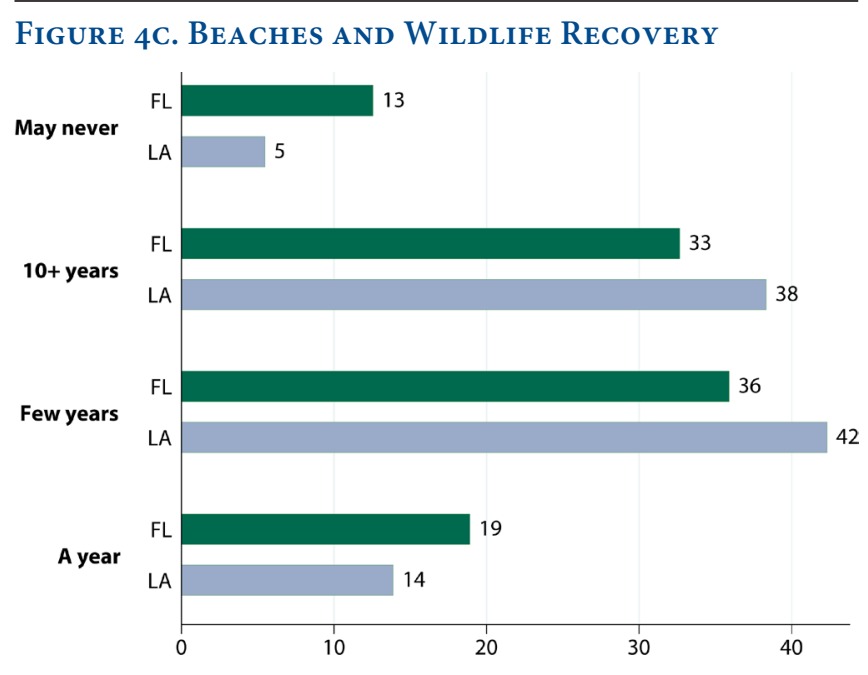

\section{Trust in Sources of Information About the Spill}

The aftermath of the spill revealed few differences in Gulf Coast residents' trust in sources of information about the oil spill. The most notable difference between Floridians and Louisianans was in how much they trusted newspapers. Thirty-seven percent of Louisianans trusted newspapers as a source of information regarding the spill, but only 30 percent of Floridians said the same.

The most trusted source of information about the spill for all respondents was scientists. Fifty-two percent said they trusted scientists for information about the spill (see Figure 5). On the other hand, only 19 percent said they did not trust scientists for information about the spill. The second most trusted source of information (by a large margin) was environmental organizations, with 37 percent of respondents saying they trusted them. These relatively high levels of trust (in comparison to newspapers, television, BP, and the internet) might be welcomed by scientists and environmental organiza-

Figure 5. Percent of Respondents who Trust SOURCES OF INFOrMation about The GUlf Oil SPILl

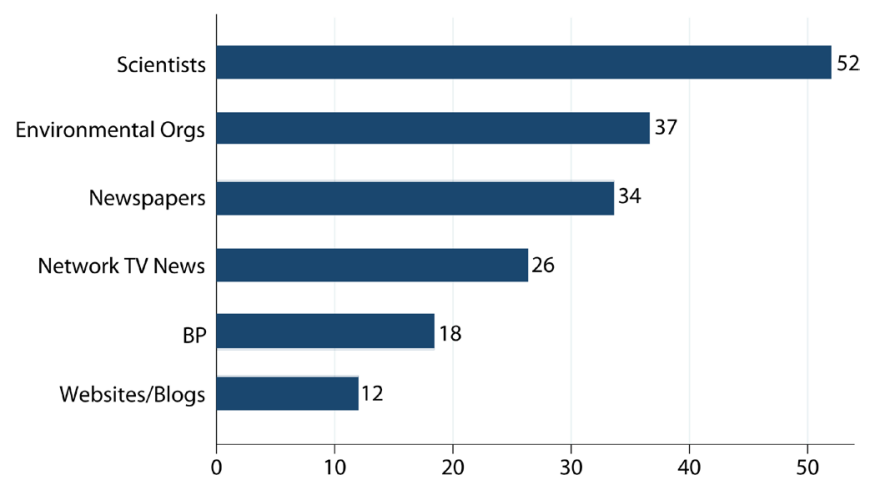

tions that have faced political criticism for speaking out on controversial environmental topics.

Network TV news, BP, and websites or blogs were the least trusted sources of information about the spill. Forty-three percent said they did not trust network TV news for information about the spill and only 26 percent said that they trusted network TV news. Only 18 percent said they trusted BP, and 59 percent said that they did not trust BP. Respondents were also very skeptical about information found on the internet, with only 12 percent trusting it, 40 percent not trusting it, and almost half of respondents (48 percent) saying that they were unsure about information provided by websites or blogs. It appears that when it comes to controversial issues like the BP oil spill, those close to the disaster prefer to get their information from sources such as scientists or environmental organizations that can more credibly provide empirical evidence about the effects of the disaster.

\section{Institutional Responses to Oil Spill}

Opinions are more polarized on the effectiveness of institutions in responding to the oil spill (see Figure 6). Although uniformly skeptical about BP's and the federal government's responses, residents held mixed perceptions about state and local governments' responses. Respondents from Florida were much more likely to think their local and state governments were doing a poor or fair job responding to the spill, while Louisianans generally thought their local and state governments were doing a good or excellent job. Perhaps local and state authorities in Louisiana were more prepared and educated in effectively reacting to natural disasters because of the intense criticism they received during and after the Hurricane Katrina crisis in 2005.

FIgURE 6. "WOULD YOU SAY THAT THE FOLLOWING INSTITUTIONS HAVE BEEN DOING AN EXCELLENT..... GOOD....FAIR...... OR POOR JOB RESPONDING TO THE OIL SPILl IN THE GULF OF MEXICO?" (PERCENT OF RESPONDENTS)

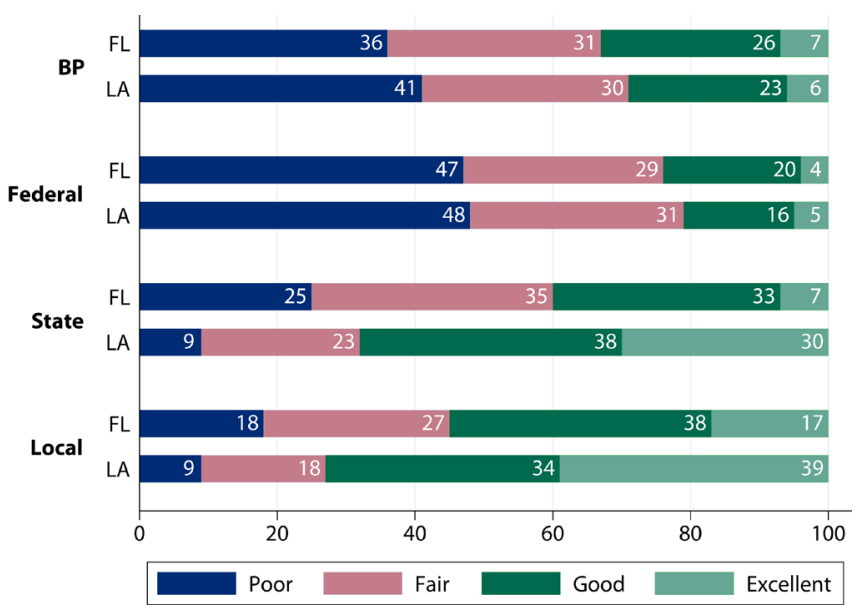


Nearly one-half of respondents ( 47 or 48 percent) in each state thought that the federal government was doing a poor job in responding to the oil spill. This disapproval rate is noticeably worse than that for BP itself (36 or 41 percent). Thus, overall, local and state responses to this disaster were better received than federal or corporate responses. Perhaps this reflects respondents' feelings that $\mathrm{BP}$ and the federal government were out of touch in their responses to the spill and not adequately addressing the true needs of Gulf residents. It may also reflect their preference for more local and state control over regional issues.

\section{Future Outlooks and the Oil Spill}

The majority of Gulf Coast residents plan to remain in the region despite the economic and environmental impacts of the spill (see Figure 7). Those planning to move because of the spill, however, are more likely to be from Louisiana than Florida. Among Louisianans, 12 percent said they planned to leave, compared with just 7 percent of Floridians. Louisianans were more optimistic about the long-term recovery of the local economy, environment, and fisheries (fewer thought that they "may never" recover) and a higher percent thought their state and local governments were more effectively dealing with the spill; however, they were more likely to plan to leave than Floridians. More Louisianans were directly impacted by the spill, with 74 percent saying that their families experienced either minor or major economic effects in comparison to 57 percent of Floridians. Louisianans may be more likely to feel they need to move because their livelihoods, which are more often tied to the heavily impacted fishing and oil industries, have been disrupted. On an optimistic note, despite the magnitude of this disaster, most Gulf Coast residents are planning to stay in their communities and are more positive about the future. Thirty-eight percent see their community as being a better place in the future in comparison to only 18 percent who see it as being worse.

Figure 7. "As A Result of THE GULF OIL SPILL, DO YOU THINK THAT YOU ARE MORE LIKELY TO MOVE AWAY FROM THIS AREA? OR HAS THE SPILL HAD NO EFFECT ON YOUR PLANS TO STAY OR LEAVE?"

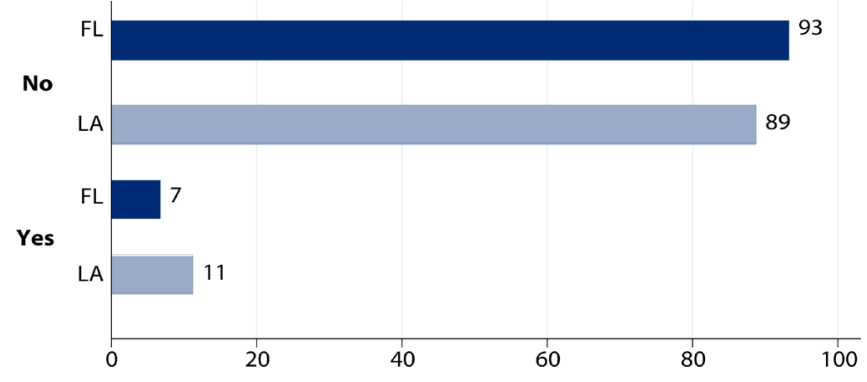

While the general public thinks about the BP oil spill as one disaster, how it affected Gulf communities depended on the underlying social, economic, and environmental conditions. Despite remarkably similar compensation from BP, this brief illustrates clear differences in how Floridians and Louisianans subjectively experienced the disaster. Respondents from the two states, with their different historical, economic, and cultural backgrounds, had markedly varying perceptions of the current and potential effects of the disaster on their families, communities, and the environment.

Notably, respondents had very different opinions about the effectiveness of a variety of institutions in responding to the spill. While we can not compare the extent of outreach in both states, Louisianans were more than twice as likely as Floridians to think that their state and local governments were doing an excellent job responding to the spill. On the other hand, the majority of all Gulf Coast residents perceived responses by $\mathrm{BP}$ and the federal government as poor or fair. In order to improve effectiveness of response efforts, local and state governments-particularly in Louisiana-should perhaps be given more control in disaster response situations from the federal government or involved companies. With regard to how information about disasters is disseminated to potentially affected populations, this survey clearly shows that people trust the information that scientists (arguably the least biased out of potential information sources) can provide. Scientists need to do a better job at outreach and disseminating information that is easily understandable to the general population.

Follow-up surveys could determine whether Gulf Coast residents' perceptions about the effects of the spill on their communities have changed as the memories and direct impacts of the spill grow distant. CERA surveys, such as the one conducted in the Gulf in the wake of the BP spill, can gather important subjective information about perceptions of changes occurring in rural America. The findings can be utilized by local leaders, policy makers, and disaster response teams to help foster healthy and sustainable communities that can rebound from (and perhaps prevent) even large-scale disasters like the BP oil spill. 


\section{E N D N O T E S}

1. As of December 2010, Louisiana had received \$698 million and Florida \$682 million. David Alderstein, "Nearly \$24 Million Paid in BP related claims," Apalachicola and Carrabelle Times, December 2, 2010.

2. Although Plaquemines and Terrebonne parishes and Bay county are within Census designated metropolitan areas, they are mostly rural in character.

3. Surveys were conducted from July 29 through September 30, 2010. Statistical tests found no evidence that the dates within this range affected how respondents answered the survey questions.

4. Many of the questions asked were identical to those in all CERA surveys; however, some common CERA questions were omitted to reduce the length of the survey and make room for others specifically about the BP oil spill.

5. For more information about the Community and Environment in Rural America (CERA) survey, please visit the CERA page on the Carsey Institute's website (http://www. carseyinstitute.unh.edu/CERA/cera-home.html).

6. All percentages using CERA data throughout this brief are calculated using weights based on recent census age, race, and sex estimates.

7. Alderstein, "Nearly \$24 Million Paid in BP related claims."

8. William R. Freudenburg and Robert Gramling, Blowout in the Gulf: The BP Oil Spill Disaster and the Future of Energy in America (Cambridge: MIT Press, 2011).

9. National Commission on the BP Deepwater Horizon Oil Spill and Offshore Drilling, "Deep Water: The Gulf Oil Disaster and the Future of Offshore Drilling," Report to the President (2011).

\section{A C K N O W L E D G M E N T S}

The author would like to thank Larry Hamilton and Tom Safford for their important contributions to the content of this brief, Justin Young for his assistance with the survey design and content, Kyle Schad and Katy Ulrich for their assistance testing survey timing and questions, and Laurel Lloyd Earnshaw, Amy Sterndale, Curt Grimm, and Judy Ulrich for their input on subsequent drafts.

\section{ABOUT THE AUTHOR}

Jessica D. Ulrich is a doctoral student in the Department of Sociology at the University of New Hampshire and a research assistant at the Carsey Institute (jessicad.ulrich@ gmail.com).

\section{ANIVERSITY}

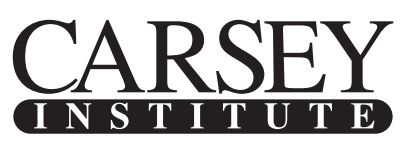

Building knowledge for families and communities

The Carsey Institute conducts policy research on vulnerable children, youth, and families and on sustainable community development. We give policy makers and practitioners timely, independent resources to effect change in their communities.

Special thanks to Jan Nisbet, Senior Vice Provost for Research at the University of New Hampshire, and to the Ford Foundation and Kellogg Foundation.

Huddleston Hall

73 Main Street

Durham, NH 03824

$(603) 862-2821$

www.carseyinstitute.unh.edu 